\title{
Arthur Lewis' Dualism, the Literature of Development Economics, and the Less Developed Economies
}

\author{
Hamid Hosseini ${ }^{1}$ \\ ${ }^{1}$ International Business and Economics, King's College, Wilkes-Barre, PA, USA \\ Correspondence: Hamid Hosseini, International Business and Economics, King's College, Wilkes-Barre, PA \\ 18711, USA. Tel: 1-570-208-5900 ext. 5696. E-mail: hamidhosseini@kings.edu
}

Received: June 23, 2012 Accepted: August 3, 2012 Online Published: August 20, 2012

doi:10.5539/res.v4n4p132 URL: http://dx.doi.org/10.5539/res.v4n4p132

\begin{abstract}
Almost 60 years ago, Arthur Lewis published his seminal, classically-based dualism paper. Assuming a modern capitalist sector in urban centers of the LDCs and a traditional agricultural sector with an unlimited supply of labor in their rural areas, the policy implications of the model was that with the right mix of economic policies and resources, the disguised unemployed labor of the rural sector will eventually be absorbed into the modern capitalist sector, thus, transforming the poor underdeveloped economies into modern dynamic ones. Obviously this transformation did not take place. Instead, the migration of the traditional agricultural workers to the cities gave rise to another dualism, the formal-informal dichotomy. In this paper, after discussing the Lewis model, its significance to the history of development economics and its refinements by Fei, Ranis and others, the causes of the failure of the model will be explored. It will be argued that the assumptions of this classically-based model did not fit the realities of most contemporary LDCs, and that it could not predict the rise, or the significance, of the informal economy in the LDCs. Next, the various dimensions, causes, characteristics, and significance of the much neglected informal sector in the LDCs will be explained.
\end{abstract}

Keywords: dualism, disguised unemployment, informal economy, modern and traditional sectors, transformation

\section{Introduction}

In 1954, in his now famous paper, Arthur Lewis - a St. Lucia (West Indies) born and U.K. educated Nobel Prize winning economist - introduced a classically-based theoretical model of economic development premised on the twin assumptions that there was an unlimited supply of labor in the traditional agricultural sector of the less developed countries and that, as the modern industrial urban sector in these countries grew, this vast pool of surplus labor would be absorbed. This model, further refined by economists such as Fei and Ranis (1964), Harris and Todaro (1970), Fields (1975), and others, dominated the literature of development economics and more during the 1950s and the 1960s. According to a 2004 essay by Kirkpartrick and Barrientos, this seminal paper by Lewis "is widely regarded as the single most influential contribution to the establishment of development economics as an academic discipline" (2004, p. 679). These two writers agree with a 1980 statement by Findlay that almost all of Lewis' subsequent work, and a large part of the literature on development economics, can be seen as extended commentary on the meaning and ramifications of the ideas set out in the 1954 paper (Kirkpatrick \& Barrentos, 2004). Proponents of that model, as Chen, Jhabvala, and Lund argue, assumed that "with the right mix of economic policies and resources, poor traditional economies could be transformed into dynamic modern economies" (2002, p. 1). In the words of Kirkpatrick and Barrientos, "Unlimited supplies of labor ensure that accumulation is sustained over time, but the dynamics of the economic forces at play lead towards economic transformation. Eventually the reservoir of surplus labor in the subsistence sector is exhausted, and wages in the subsistence sector begin to rise..." (2004, p. 682). Needless to say that in Africa and most countries of Asia and Latin America this transformation did not take place (and the optimism about economic growth prospects in those countries began to give way to concerns about persistent widespread unemployment in the urban sector). It seems that while people left the traditional agricultural sector for the modern capitalist centers, the modern-formal capitalist sector was unable to absorb them, or even absorb some of the unemployed in the urban centers. As a result, because capital-intensive production did not require much labor, a different dichotomy became pronounced in the urban centers of these countries - that of formal versus informal 
economies. However, although acknowledged by some writers, this dichotomy has been neglected by development economists who, if acknowledging it at all, have often subscribed to the notion that the informal economy in the urban centers of the LDCs is only marginal or peripheral. In the words of Chen, et al, the concept of informality has "failed to capture the attention of mainstream development economists in any significant way" (Ibid, p. 2). For example, several years ago, Gustav Ranis and Frances Stewart acknowledged this dichotomy when they wrote: "estimates of the size of the urban informal sector across the developing world indicates that in most countries it is substantial, in many cases accounting for over half the urban workforce, with the highest in some African countries. Moreover, data over time show a rise in almost all LDCs during the 1970s and 1980s" (1999, p. 271). However, four years later, Gustav Ranis downplayed the importance of the informal sector, while finding the (Lewis-based) dualism model still relevant. In that paper, entitled "Is Dualism Worth Revisiting?" Ranis states that "We found that the basic dualism model well fits the historical experience of such countries as England, Japan, and Taiwan, and believe it is likely to continue to be relevant for China, India, parts of Africa, and Latin America, among others" (2003, p. 17).

I will argue that the Lewis model (and its refinements) cannot provide a solution to the problem of poverty and underdevelopment in much of the contemporary world. For, its assumptions do not correspond to the realities of most present day LDCs, and it fails to explain the reality of the formal versus informal sectors in the less developed countries. (Needless to state that I disagree with Gary Fields' argument in his 2004 essay that informality is the same as subsistence, traditional, agriculture, or rural). After all, a large share of the productive and exchange activities of the LDCs takes place in the informal sector which is unexplained in that model. As stated by Friedrich Schneider, "On average the size of the informal economy in Africa (in percent GDP) was $42 \%$ for the years 1999/2000. Zimbabwe, Tanzania, and Nigeria with 59.4, 58.3, and 57.9\% have by far the largest informal economy" (2000, p. 5). And, Africa is not by any means the exception. According to Centeno and Portes, "The rise and continuity over time of a vast informal sector is perhaps the most glaring example of the characteristics peculiar to Latin America..." (2003, p. 3).

In this paper, I will first describe the Lewis dualistic model, its significance in the history of development economics thought, and its extensions by Fei and Ranis and others. Next, I will discuss the difficulties of its application to the realities of contemporary less developed countries. Following that section, I will discuss the neglected informal sector in the LDCs. More specifically, I will discuss its nature, characteristics, its causes, and the relationship it has with the formal economy and the state (government). Since it occupies a very large segment of the economies of the LDCs, which is not recorded in GDP (and PPP) calculations; it also makes sense to discuss the costs of informality, and the benefits this sector provides in the less developed economies. As we will see, while the informal sector is costly to the LDCs because it frustrates the development process and weakens government development policies, it is also helpful as a cushion and a source of income for otherwise incomeless individuals.

\section{The Lewis Model and Its Significance in Post World War II Development Economics}

Prior to World War II, the study of the economies of the less developed countries was by and large neglected by the economics profession. The extent of this neglect becomes obvious if one reads the 1938 World Economic Survey of the League of Nations. We are reminded by H. Arndt that this "world" report, prepared by future (i.e. 1977) Nobel Prize winner James Meade, had only one paragraph about Latin America, and made no mention of the economic situations of the countries of Asia and Africa (mostly then under European/Western Colonial Rule) (1987, p. 33). The works of great pre-war economists were not any different - they too ignored non-western/less developed economies. Development economics, as a distinct body of economic thought that deals with the less developed countries, is essentially a post WWII phenomenon. One might argue that it began with Paul Rosenstein-Rodan's 1943 Economic Journal essay "The Problems of Industrialization of Eastern and Southern Europe". Interestingly enough, even this important essay discusses the problems of the poorer regions of Europe, rather than the less developed countries of Asia, Africa, and Latin America. Development economics emerged, perhaps, as a by product of economic growth, at a time when, as argued by Amartya Sen, "growth was everybody's concern" (1970, p. 9).

During its formative years, development economists applied the available models (like the Harrod-Domar model, which had been constructed for more developed economies) to the problems of the less developed countries. As argued by Gustav Ranis, the growth models of the day had: "little relevance for societies not primarily concerned with business cycles or steady state properties" $(2003$, p. 1). To him, these development economists should have viewed these models: "as advanced country - related, relatively abstract theoretical constructs, faithful to the dominant assumptions of neo-classical macro-theory: full employment, market clearing and perfect competition, all of which seemed to have little relevance for the segmented commodity, labor, and credit markets of the poor 
countries" (Ibid).

It was against this background that the concept of dualism, with roots in the French physiocrat's tableau economique and Ricardo's Principles, attracted attention among development economists during the 1950s and 1960s. According to Kirkpatrick and Barrientos, the debate following the 1954 paper by Arthur Lewis focused on Lewis' return "to the classical economists for an analytical framework relevant to countries with surplus labor Lewis' optimistic vision of rapid capitalist accumulation and economic transformation was grounded on a dualistic economy." (2004, p. 685). Development economists Boeke (1953), Eckaus (1955), and Higgins (1956) were among the first to emphasize the problem of dualism in the less developed countries. To Gustav Ranis, in some ways even economists such as Rosenstein-Rodan (1943), and Mandelbaum (1945) had pointed to the existence of surplus labor as a potential source which, once reallocated from agriculture to higher productivity pursuits in non-agriculture, would function as a major fuel for development (2004, p. 4). Of course, as Ranis also agrees, it was Nobel Laureate Arthur Lewis who, in his classic 1954 paper (which is rooted in the classical tradition), focused more precisely on dualism in labor markets. To Ranis, like Adam Smith in the Wealth of Nations, Arthur Lewis saw: "the relatively small non-agricultural commercialized sector as the dynamic partner, expanding and fed by the mobilization of the hidden rural savings which Nurkse and Rosenstein-Rodan had identified" (2004, p. 5). According to Arthur Lewis, the reallocation process in the poor countries would continue until the surplus agricultural labor (with zero marginal product of labor) moves out of agriculture into commercialized non-agriculture causing a turning point at which time dualism would disappear and the less developed economies would be transformed into developed capitalist ones. Put it differently, in the Lewis' development model, the underdeveloped economy consists of two sectors. The first being a rural subsistent and overpopulated sector in which marginal productivity of labor is zero. It is this assumption that gives rise to a surplus labor and disguised unemployment, enabling the withdrawal of labor from the traditional agricultural sector without causing a loss of output (To Lewis, rural workers share equally in the output so that the rural wage is determined by the average and the marginal product of labor, as is the case in the modern capitalist sector).

The second sector in Lewis' model is the modern industrial sector which is high in productivity. It is this modern sector to which the labor from the traditional subsistence sector is transferred. Arthur Lewis's model emphasizes the process of labor transfer as well as the growth of output and employment in the modern industrial sector. These two become possible only because of the output expansion in the modern sector. Of course, in this model, the rate of output expansion is determined by the rate of capital accumulation and industrial investment in the capitalist sector. These become possible by the excess of modern sector profits over wages assuming that the capitalist owners of modern industrial enterprises will reinvest their excess profits in the modern sector of their own country, rather than investing it in more advanced countries (i.e. capital flight) and other options (Such as consuming excess profits on luxury goods).

According to Gustav Ranis, Lewis' 1954 paper focused mainly on organizational dualism (and on intersectoral labor markets only implicitly). To him, Lewis did not have a lot to say about intersectoral commodity markets, or the intersectoral terms of trade. These extensions took place in the works by Fei and Ranis (1964), Harris and Todaro (1970), Fields (1975), and others. For example, while Lewis' implicit arguments included the significance of balanced growth between the two sectors, it was left to Fei and Ranis (1964) to make the argument explicit-by superimposing product dualism on Lewis' organic dualism so that food shortages could lead to a rise in the real agricultural wage and, consequently, the real wages of unskilled industrial workers. These would take place before the Lewis' turning point could be reached, which would signal the exhaustion of labor surplus. And Harris and Tortado (1970) extended Lewis' model by arguing that intersectoral labor reallocation is affected not only by the intersectoral wage gap, but also by the probability of obtaining jobs in the modern sector. Harris and Todaro emphasized institutional interventions in improving the level of non-agricultural urban unskilled real wage, arising from unions, minimum wage, and government's attempt to set wages. While this was consistent with what Lewis called intersectoral hill, Harris and Todaro emphasized it in terms of a competitive neoclassical agricultural wage.

On the basis of Lewis's 1954 model, and its extensions in the hands of Fei and Ranis (1964) and others, one would have expected the realization of the Lewisian turning point in the less developed countries, thus the absorption of their traditional agricultural workers (moving to the urban centers) into their modern capitalist sectors, in other words, implying the relevance of the model to those LDCs. As stated in the Introduction, Gustav Ranis, in his 2003 paper, argued that the model did fit the historical experience of countries like England, Japan, and Taiwan. And, more importantly, it will also be applicable to the experience of many developing countries in the future (2003, p.17). However, Charles Kindleberger casted doubt even in terms of its exact fit during the (European) industrial revolution (in the sense that its true fit needs some adjustments): "The Lewis model fit the 
industrial revolution insofar as the wave of inventions between 1766 and 1775 raised marginal returns to labor in industry and let loose a flood of workers moving off the farm. One might want to adjust the model to allow for three sectors, two in industry, one monopolized by guilds (which were not affected), and the other outside of the range of the guilds. Innovations underway in agriculture spread, and especially profits in industry were reinvested" (1988, p. 18).

In terms of its relevance to the developing economies, according to Chen, Jhabvala, and Lund, its policy prescriptions "did not create modern jobs to reduce unemployment or erode the traditional sector" (2002, p.1).

How do we explain this lack of fit (thus not giving rise to the Lewisian turning point)? In Section III, I will present two arguments. One, that its assumptions about the LDCs were not terribly realistic. Second, that the Lewis model did not anticipate the substantial increase in and the significance of the informal economy in those countries. (Although Lewis assumed a dualistic model, he was also aware of the elements of informality. In the 1954 paper, he made a reference to the formal-informal dichotomy on pages 141 and 142).

\section{Arthur Lewis’ Assumptions and Contemporary LDCs: Are they Realistic?}

As many writers have argued, the classical-based two-sector Lewis model reflects the economic growth of various European countries of the past few centuries. As a result, some of the assumptions of this dualism model do not seem to capture the realities of at least most contemporary LDCs, explaining why the Lewisian turning point did not occur in those countries, and why the afore-mentioned dichotomy of formal versus informal economies has become so significant. According to Chen, Jhabvala, and Lund, Lewis' classically-based model failed to predict the persistence of many traditional forms of employment, or the emergence of new forms of non-standard types of employment. In other words, the Lewis model failed to predict that the formal-informal dichotomy is paramount in the present day LDCs, and that it will not disappear for years to come (2002). It is for this reason that for writers such as Centeno and Portes, the application of this model to the LDCs is inappropriate (2003, p. 3).

As we are reminded by M. Todaro and S. Smith, the Lewis model implicitly assumes that the rate of labor transfer and employment creation in the modern capitalist sector is proportional to the rate of capital accumulation in this modern sector.(2003, p. 120). As a result of this assumption, then, the faster the rate of capital accumulation, the higher the growth rate of the modern sector and the faster will be the rate of job creation. But, what if capitalist profits are reinvested in more sophisticated labor saving capital equipment rather than just duplicating the existing capital as is implicitly assumed in the Lewis model? The model also assumes that capitalist profits are in fact reinvested in the local economy and are not sent abroad as a form of capital flight - as has often been the case - to be invested in more advanced economies, or even be kept and deposited in Swiss or other Western banks (Besides, as post 1954 research has demonstrated, in addition to physical capital, development also requires human and social capital which have been inadequate in most of LDCs).

A second questionable assumption of the Lewis model is the notion that surplus labor exists in the rural sector while there is full employment in the modern urban sector. The notion that surplus labor exists, with the implication that there is disguised unemployment with zero marginal productivity of labor, has been criticized by many writers. This assumption, used in the works of Paul Rosenstein-Rodan, Ragnar Nurkse, and Arthur Lewis, was challenged as early as 1957 by Jacob Viner, to be followed by T.W. Schultz in 1964. Jacob Viner and T.W. Schultz demonstrated that while the marginal productivity of agricultural labor may be quite low in the (traditional sector) of the less developed countries, it is not zero and hence surplus labor does not exist.

Another unrealistic feature of the Lewis model is the assumption of a competitive modern-sector labor market that leads to the continued existence of constant real urban wages up to the point where the supply of real surplus labor is exhausted (Todora and Smith, 2003, p. 121). According to these two writers, prior to the 1980s, "a striking feature of urban labor market and wage determination in almost all developing countries was the tendency for these wages to rise substantially over time, both in absolute terms and relative to average rural incomes, even in the presence of rising levels of open modern-sector unemployment and..." (2003, p. 121).

In their 2004 paper, Kirkpatrick and Barrientos too discuss the criticisms leveled by various development economists against the application of the Lewis model to today's LDCs. They summarize these criticisms leveled against the Lewis model as follows: "Criticism of the model turned on the validity of his central postulates that the subsistence sector in developing countries contains an abundance of labor, ensuring that the conventional wage in the subsistence sector rules over the entire economy. Other criticisms interpreted the Lewis model as advocating industrialization and the neglect of agricultural development. Criticism was also made of the assumed process of labor migration from the subsistence sector to wage employment in the capitalist sector, especially in the light of rising unemployment observed in developing countries... The model was also criticized for its 
neglect of the role of international trade, and for assuming that the capitalist surplus would be reinvested in full." (2004, p. 684).

Based on the above arguments, i.e. the labor-saving bias of most modern technological transfers, the existence of a substantial amount of capital flight to more advanced and stable economies, the relative absence of rural surplus labor and disguised unemployment, the existence and prevalence of urban surplus labor, the importance of international trade, the fact that wages in the modern sector rise even where unemployment exists, and for other shortcomings of the model ,one has to agree with Todaro and Smith that: "the Lewis two-sector model though extremely valuable as an early conceptual portrayal of the development process of sectoral interaction and structural change - requires considerable modification in assumptions and analysis to fit the reality of contemporary developing nations" (Ibid, p. 121).

\section{The Formal versus Informal Dichotomy and Its Significance}

One reason for the need for the modification of the Lewisian model has to do with the tremendous increase of the informal sector in the LDCs which really had not been anticipated by the Post - World War II proponents of dualism. The rise of the formal-informal dichotomy, whose elements had existed in the urban centers of the less developed countries before, went unnoticed by development economists for a long time. It was first acknowledged during the 1970s, when various economists began to notice a rising sector of the economies of the less developed world that did not fit the assumptions of development models, including the Lewis-type of models. They observed millions of individuals whose means of survival were not detected by traditional measures used by economists. For, these people did seem to own land; they did not appear to possess any assets; they were not employed formally; they did not own any pension; and, they lacked a regular flow of economically (i.e. formally) detectible incomes. But somehow these millions of people managed to survive.

As observed by Keith Hart and labor economists at International Labor Organization (ILO), what was taking place in the LDCs was that (instead of being transformed to formal workers in the modern formal capitalist sector, as predicted by the Lewis model), many traditional agricultural workers (and urban unemployed workers unable to find employment in the formal sector) were being transformed into the informal/hidden workers in the urban sector of the economy in those countries. As suggested by Klarita Gerxhani, Keith Hart (1973) introduced the term informal economy (initially only for the LDCs) into the academic literature (2003, p. 4). Keith Hart utilized the concept to explain that segment of the urban labor force which functions and works outside the formal sector of the economy. In other words, to describe the various often self-employed individuals who make a living outside the formal labor market - either as an alternative to the formal sector, or as a means of supplementing income earned in the formal sector (But, to Marilyn Carr and Martha Alter Chen, the term was actally coined by the ILO Mission to Africa in 1971, and not by Hart later). As suggested by Gerxhana, the introduction of the concept made it possible to incorporate economic activities that were previously ignored in the theoretical models of development. According to Centeno and Portes, in his 1973 report to the ILO, "Hart postulated a dualist model of income opportunities of the urban labor force, based largely on the distinction between wage employment and self-employment. The concept of informal economy was applied to the self-employed. Hart emphasized the notable dynamics and diversity of these activities which, in his view..." (2003, p. 4).

\section{A Good Definition of the Informal Economy and Why Has It Continued to Grow in the LDCs}

To understand what is meant by the informal economy, we should keep in mind the distinctions between illegal enterprises and workers, and informal enterprises and workers on the one hand, and between formal and informal enterprises and workers on the other. We can also make a distinction between informality and shadow economy. While illegal enterprises and workers engage in the production and exchange of what a country regards as illicit goods and services, informal enterprises and workers for the most part engage in the production and exchange of what a nation regards as licit goods and services. In other words, the distinction between illegality and informality is made on the basis of the character of the final product. For example (since Islamic law forbids the production and use of alcoholic beverages), in Iran under the Islamic Republic, or in Saudi Arabia, the production of alcoholic beverages would be illegal, but those of any legal good by an informal enterprise would be informal. However, the distinction between formality and informality is not in terms of the character of the final product, but about the manner in which the good or service is produced and exchanged. Very licit goods, like food, clothing, housing, and automobile, would be viewed as formal if they have their origins in the legally sanctioned production and exchange arrangements. However, the very same licit goods and services may be viewed as informal if they bypass official rules and laws of a given society. As stated in the Introduction, informality is also different from the shadow economy. As demonstrated later, informality has emerged not so 
much to avoid paying taxes and obeying regulation, but as a desperate attempt for otherwise unemployed persons to have some sort of income. But, those included in the shadow economy have avoided paying taxes and following regulations.

Various individuals in the urban areas of the less developed world are engaged in the production and exchange of goods we can call informal. About India, Martha Alter Chen writes: "The sidewalks are lined by barbers, cobblers, waste recyclers, and venders of vegetables, fruits, meat, fish, snack-food and a myriad of nonperishable items ranging from locks and keys, soaps and detergents, to clothing. Head-loaders, cart pullers, bicycle peddlers, rickshaw pullers. On the street corners, even in some residential areas, there are countless small kiosks or stalls that sell goods of every conceivable kind." (1999, p. 1). Various writers have argued that a substantial part of the population of LDCs operates in the large but hidden sector of the economy that is not recorded in the GDP or PPP (i.e. formal) statistics. It is generally believed that the value of economic transactions in these markets may match or even exceed what is recorded in at least parts of the formal economic sectors in the developing world.

The concept of informal economy was born in the Third World, out of a series of studies on urban labor markets in Africa (Centero \& Portes, 2004, p. 4). But Martha Chan reminds us that this is not by any means confined to the LDCs. To her, pushcart vendors, street vendors, side-walk performers and actors in New York City too belong to the informal economy. However, to some writers, this phenomenon may be found only in certain parts of the developed world. This is evident in the following statement by Theodore Shanin: "I remember going to Italy in the 1980s, when Italy and England both had very high rates of unemployment. But while I saw the unemployed everywhere in northern cities in England, in Italy I could not find them. Everyone was employed doing something, in hundreds of very informal ways. Much of it I don't suppose the taxman knew about."(2004).

Why has this phenomenon grown so much in the LDCs in recent decades? Has it really grown or has this long been the situation. Because of the perception of relative attractiveness of life in the urban centers of the LDCs, the existence of more opportunities and possibilities in the cities, and the phenomenon of demonstration effect, on the one hand, but the relative backwardness of the countryside on the other, many of the youth in the countryside have moved to the cities of the LDCs. This has given rise to a tremendous increase in the supply of labor in those urban centers. There are also those unemployed persons in the urban centers who are unable to find employment. However, the modern (formal) capitalist urban centers have not had the capacity to absorb the entire labor force. And, no universal public welfare system has existed to formally provide assistance to these unemployed people. In fact, many of the LDCs have had little or no growth to absorb the surplus labor. And, in certain cases, even if they have witnessed growth, because they have pursued more capital-intensive processes, their economic growth has often been a jobless one. As a result, these unemployed workers with no public support seek employment, or start their own work, in the informal economy. Economic crises, and the closure or the downsizing of public enterprises in certain countries too may lead to the rise of informal sector employment, particularly for those with lower skills. According to Chen, globalization, which has been to the advantage of large companies and to the disadvantage of small and micro enterprises, too has caused the growth of the informal sector. For "globalization puts pressure on low-skilled workers and petty producers by weakening their bargaining power and subjecting them to increasing competition" (1999, pp. 2-3). This increased competition too forces many formally employed persons into the informal sector.

In the less developed world, it can then be argued, there exists now a major type of dualism consisting of the formal and the informal sectors, the informal economy being symptomatic of the failure of their economies to achieve sufficient and sustainable economic growth, thus to absorb the unemployed.

Because of the absence of sufficient economic growth and sufficient public assistance, the informal sector has emerged to provide income or a safety net for the unemployed and the poor. And, this sector has persisted because these economies have failed to absorb those employed in the informal sector (in addition to the new ones added). Of course, there exist other explanations which, in my view, are applicable to the economies of more advanced nations. For example, DeSoto (1990) perhaps being influenced by the Public Choice school in the United States, views informality from a legalistic perspective. To him, the rise of informal enterprises, as unregistered businesses, should be viewed as rational responses to over-regulation by government bureaucracy. Thus, to him, informality emerges by certain enterprises in an attempt to reduce their costs and thereby increase their profits. This, it seems to me, cannot be substantiated in most less developed countries. According to the Principal Resolution of the 2003 Ahmadabad Conference on the Informal Economy, "Most people enter the informal economy because of a need to survive, not out of choice".

\section{The Informal Economy and the State: What Are the Benefits and Costs of Informality?}

The government (i.e. the state) in any modern economy performs at least three economic functions of regulative, 
the enforcement of those regulations, and taxation. In its regulative function, the state defines and establishes the legal framework and the rules and laws necessary for the economy to function. In its enforcing function, having monopoly of power, it enforces those laws and regulations for businesses. And, to have the means of regulation and enforcement, it utilizes its monopoly of power to levy and collect taxes from the populace. These three functions of the state can be utilized to provide another definition of informality. On the basis of these three functions, informality occurs when economic agents (i.e. owners of enterprises or those working for these enterprises) bypass (or violate) all of these three functions. In other words, none of these three connections are being made in the case of informality, suggesting an inevitable conflict between the government and the informal sector. Thus, economically, the more expansive the informal sector, the weaker would be the monopoly power of the government. Centeno and Portes argue that: "An informal economy will develop when and where it can. This is not just true of underdeveloped/economies, but of the informal economies of richer countries."(2003, p. 8).

Although the informal sector escapes the formal economy and does not contribute to the revenue stream needed for the functioning of the government, it is not without its share of benefits to the economy. As argued by Pius Simon, the informal "sector provides strategy for the urban poor who are excluded from regular wage employment."(2004, p. 1). For, as stated in the Principal Resolution of the 2003 Ahmadabad Conference on the Informal Economy, those who enter the informal sector "are insecure and unprotected and generally poor". Because (in the LDCs) "most people enter the informal economy because of a need to survive, not out of choice". As a result, it is argued, informality helps to make the LDCs more stable; it can be viewed as a lubricating device, a social arbitrage and an unofficial safety net.

The informal economy can also provide the workers of the formal sector with lower prices for consumer goods, since, paying no rent (operating on sidewalks, etc.), taxes, etc., informal enterprises have lower costs than the formal ones. This, in effect, will also lower the cost of production and distribution for the firms in the formal sector, and lower prices for consumers.

Although the informal sector in the less developed world has the above-mentioned benefits, it is also costly to these countries. In general, we can argue, the problem of informality perpetuates the situations that cause economic underdevelopment. In effect, it locks in place the conditions that make LDCs peripheral. For example, as various development economists (including those associated with the World Bank) have argued recently, sustainable economic development in the less developed world, in addition to physical and human capital, also needs an adequate amount of social capital, as social glue that makes the required coordinated activity possible. However, the rise and expansion of informality, as witnessed in the LDCs, undermines social capital and its various elements. Informality also weakens the authority and effectiveness of the state to enforce the much needed development policy in those countries, and frustrates the resolution of collective action. In explaining this, Centeno and Portes, utilizing Albert Hirschman's exit metaphor, argue that: "given the attraction or inevitability of an informal exit, the state has great difficulty in building required loyalty." $(2003$, p. 17). The existence of a large informal economy limits public incentives needed to create the conditions for modern capitalist development. Informality, particularly since it weakens the pool of national social capital, discourages investment in the types of institutions needed for economic development.

The public provision of benefits such as long term health services, retirement, unemployment compensation and social services, which require economic formality, is also frustrated by the pervasiveness of informality. The same are also true of the protection of property rights and the prevention of environmental degradation. To be able to function, the informal sector needs to receive public benefits such as the use of sidewalks, squares, or even streets. However, it receives such benefits without contributing to their funding.

Some argue that pervasiveness and the perpetuation of informality would also perpetuate economic and social inequalities. According to Carr and Chen, "There is a link between working in the informal economy and being poor. Average incomes are lower in the informal economy than in the formal sector. As a result, a higher percentage of people working in the informal economy, relative to the formal sector, are poor." (2001, p. 3).

\section{Concluding Remarks}

As stated before, during the mid 1950s, Arthur Lewis, as one of the pioneers of what we now call development economics, presented a dualistic model of economic development premised on the twin assumptions that there was an unlimited supply of labor in most less developed countries and that, as the modern industrial capitalist sector in these sectors grew, this vast pool of surplus labor would be absorbed (by the modern sector) (1954). During the 1950s and into the 1960s, as Chen, Jhabvala, and Lund argue, "The Lewis model of economic development - reinforced by the successful rebuilding of Europe and Japan and the expansion of mass production in Europe and North America after World War II - dominated the economic discipline and 
development perspectives more broadly".(2002, p. 1). It was assumed that, with the right combination of policies and resources, poor traditional economies could be transformed into developed industrialized economies, with the urban industrial sector absorbing the surplus labor of the traditional agricultural sector and make it disappear. That, obviously, did not take place. As the 1960s was coming to its end, the optimism about economic growth prospects in the less developed world began to give way to concerns about persistent and widespread urban unemployment, in part because of the migration of traditional agriculture workers to the cities. It was as a result of this concern that, during the early 1970s, the International Labor Organization (ILO) began sending employment missions to various less developed countries. It was the 1972 Kenya ILO mission that recognized the expansion of the urban sector we now call the informal economy (but the term being coined by Keith Hart). According to Paul Bangasser (2000), the informal sector activities, which even include productive efficient enterprises, are largely ignored, rarely supported, and sometimes are even actively discouraged by policy makers and governments in the LDCs. They were also ignored by development economists. For, many assumed optimistically that the phenomenon will disappear when countries like Kenya and other less developed economies would observe higher rates of economic growth and modern industrialization. As a result, as Chen, Jhabvala and Lund argued, the informal sector: "failed to capture the attention of mainstream development economists in any significant way" $(2002$, p. 2). This is in spite of the fact that this sector "has persisted far longer than predicted in most developing countries and has expanded in many developing countries. Furthermore, the informal economy has expanded in many transitional economies and in some developed countries. Over the past decade or more, informal work is estimated to account for more than half of the new jobs in Latin America and over the 80 percent of the new jobs in Africa" (Ibid, p. 3). By emphasizing that the Lewis model (and its extensions) is no longer applicable to the realities of at least most of today's LDCs, and that economic informality has persisted, my hope is that the informal sector would be taken more seriously not only by development economists, but also by policy makers of the LDCs and by global institutions that deal with the economies of those countries.

\section{Acknowledements}

The author wishes to acknowledge the helpful comments by: the editor (Paige Dou), the referees, and King's College's Dr. Margarita Rose.

\section{References}

Arndt, H. (1987). Economic Development: The History of an Idea. Chicago: The University of Chicago Press.

Bangasser, P. (2000). The ILO and the Informal Sector: An Institutional History, Working Paper. ILO, Geneva.

Carr, M., \& Martha, C. (2001). Globalization and the Informal Economy. How Global Trade and Investment Impact on the Working Poor. ILO Task Force on the Informal Economy, Geneva.

Centeno, M. A., \& Portes, A. (2003). The Informal Economy in the show of the State. In P. Fernandez-Kelly, \& J. Sheffner. The Informal Economy in Latin America. Princeton, N.J., Princeton Univ. Press.

Chen, M. (1999). Rethinking the Informal Economy.

Chen, M. R., Jhabavala, \& Lund, F. (2002). Supporting Workers in the Informal Economy: A Policy Framework. Employment Center, the ILO, Geneva.

DeSoto, H. (2000). The Mystery of Capital: Why Capitalism Triumphs in the West and Fails Everywhere Else. New York, Basic Books.

Fei, J., \& Gustav, R. (1964). Development of the Labor Surplus Economy: Theory and Policy. Homewood, IL, Richard Irwin, Inc.

Fields, G. (2004). Dualism in the Labor Market: A Perspective on the Lewis Model after Half a Century. The Manchester School, 72(6), 724-735.

Fields, G. S. (1975). Rural Urban Migration, Urban Unemployment and Job Search Activity in LDCs. Journal of Development.

Gerxhani, K. (2003). The Informal Economy in Developed and Less Developed Countries: A Literature Survey. Amesterdam Institute for Advanced Labor.

Harris, T., \& Todaro, M. (1970). Migration, Unemployment, and Development: A Two Sector Analysis. American Economic Review, 40, 126-142.

Harth, K. (1973). Informal Economic Opportunities and Urban Employment in Ghana. Journal of Modern African Studies, 11(1), 61-89. 
Hosseini, H. (2003). Why Development is More Complex than Growth: Classifying Some Confusions. Review of Social Economy, LXI(1), 91-110.

Kindleberger, C. (1988). W. Arthur Lewis Lecture: The Lewis Model of Economic Growth with Unlimited Supplies of Labor. The Review of Black Political Economy, 15-24.

Kindlegerger, C. (1988). W. Arthur Lewis Lecture: The Lewis Model of Economic Growth with Unlimited Supplies of Labor. Manchester School of Economic and Social Students, 22, 139-191.

Kirkpatrick, C., \& Armando, B. (2004). The Lewis Model after 50 Years. The Manchester School, 72(6), 679-690.

Lewis, A. (1954). Economic Development with Unlimited Supplies of Labor. The Manchester School, 22, 139-191.

Ranis, G. (2003). Is Dualism Worth Revisiting?. Economic Growth Center, Yale University.

Ranis, G. (2004). The Evolution of Development Thinking: Theory and Policy. Annual World Bank Conference on Development Economics. Washington, D.C.

Ranis, G., \& Frances, S. (1999). V. Goods and the Rule of the Informal Sector in Development. Economic Development and Cultural Change, 47(2), 259-288.

Rosenstein-Rodan, P. (1943). Problems of Industrialization of Eastern and Southern-Eastern Europe. Economic Journal, 53, 202-211.

Schnider, F. (2002). Size and Measurement of the Internal Economy in 110 Countries Around the World. 2002 Workshop of Australian National Tax Centers.

Schultz, T. W. (1964). Transforming Traditional Agriculture. New Havan, CT, Yale Univ. Press.

Shanin, T. (2004). How the Other Half Lives.

Simon, P. (1988). Informal Responses to the Crisis of Urban Employment. An Investigatin. Regional Studies, 32.

Todaro, M., \& Smith, S. (2003). Economic Development. Boston Addison-Wesley.

Viner, J. (1957). Some Reflections on the Concept of Disguised Unemployment. Indian Journal of Economics, $38,17-23$. 